Brazilian Journal of Microbiology (2009) 40: 649-654

ISSN 1517-8382

\title{
A THIN LAYER ELECTROCHEMICAL CELL FOR DISINFECTION OF WATER CONTAMINATED WITH STAPHYLOCOCCUS AUREUS
}

\author{
Isabel C. P. Gusmão ${ }^{1}$, Peterson B. Moraes ${ }^{1}$, Ederio D. Bidoia ${ }^{1}$ *
}

${ }^{1}$ Universidade Estadual Paulista, Instituto de Biociências, Departamento de Bioquímica e Microbiologia, Rio Claro, SP, Brasil.

Submitted: August 11, 2008; Returned to authors for corrections: February 19, 2009; Approved: May 03, 2009.

\begin{abstract}
A thin layer electrochemical cell was tested and developed for disinfection treatment of water artificially contaminated with Staphylococcus aureus. Electrolysis was performed with a low-voltage DC power source applying current densities of $75 \mathrm{~mA} \mathrm{~cm}^{-2}(3 \mathrm{~A})$ or $25 \mathrm{~mA} \mathrm{~cm}$ (1 A). A dimensionally stable anode (DSA) of titanium coated with an oxide layer of $70 \% \mathrm{TiO}_{2}$ plus $30 \% \mathrm{RuO}_{2}(\mathrm{w} / \mathrm{w})$ and a $3 \mathrm{~mm}$ from a stainless-steel 304 cathode was used in the thin layer cell. The experiments were carried out using a bacteria suspension containing $0.08 \mathrm{M}$ sodium sulphate with chloride-free to determine the bacterial inactivation efficacy of the thin layer cell without the generation of chlorine. The chlorine can promote the formation of trihalomethanes (THM) that are carcinogenic. S. aureus inactivation increased with electrolysis time and lower flow rate. The flow rates used were 200 or $500 \mathrm{~L} \mathrm{~h}^{-1}$. At $500 \mathrm{~L} \mathrm{~h}^{-1}$ and $75 \mathrm{~mA}$ $\mathrm{cm}^{-2}$ the inactivation after $60 \mathrm{~min}$ was about three logs of decreasing for colony forming units by $\mathrm{mL}$. However, $100 \%$ inactivation for $S$. aureus was observed at $5.6 \mathrm{~V}$ and $75 \mathrm{~mA} \mathrm{~cm}^{-2}$ after $30 \mathrm{~min}$. Thus, significant disinfection levels can be achieved without adding oxidant substances or generation of chlorine in the water.
\end{abstract}

Key words: $S$. aureus, disinfection, treatment of water, thin layer cell

\section{INTRODUCTION}

The drinking water chlorination may affect its taste and scent, generating hazardous oxidation by-products during treatment, mainly chloramines and trihalomethanes (THM), which are mutagens and carcinogens in organic matter presence (11). Basically, electrochemical oxidation can be achieved through the hydroxyl radical $\left(\mathrm{OH}^{\circ}\right)$ formed by water discharge in dimensionally stable anodes (DSA). The "reactive oxygen" derived from the hydroxyl radical can

"Corresponding Author. Mailing address: Instituto de Biociências, Departamento de Bioquímica e Microbiologia - São Paulo State University - UNESP. 13506-900, Rio Claro, SP, Brasil. Tel.: (+5519) 3526-4191, Fax: (+5519) 3526-4176. E-mail: ederio@rc.unesp.br 
oxidize microorganisms (7). Also, discharge of water in unbuffered suspension plays an important role in killing microorganisms due to the $\mathrm{pH}$ gradient near the electrode (16).

Various electrode materials have been tested for electrochemical water disinfection, focusing on the applied potentials and killing mechanisms. Experiments comparing the performance of anodic materials have been carried out with oxide electrodes $(13,2)$, activated carbon fiber (12), platinum-clad niobium mesh (10), palladium-coated carbon cloth (19), doped diamond (17), etc. However, most of these materials are only conventional for scientific purposes, but not available in large-scale or economically appealing engineering applications.

Likewise, other methods related to electrolysis or electrical current effects have also appeared, such as disinfection using metal ions generated by electrolytic processes (9), electric inactivation of bacteria in sea water and saline wastewater (18) and electrolytic generation of biocides (22).

Recently, oxide-coated electrodes are used in many studies of electrochemical treatment of water containing organic pollutants. These electrodes and are known as Dimensionally Stable Anodes (DSA) (8) as they are more durable and low cost to maintain. The use of DSA in largescale water-treatment systems is favored by the ready accessibility of this technology from the chlorine-alkali industry, in which they are employed in electrolyzers (14).

Electrolytic treatment using DSA can improve water disinfection because the addition of a large amount of chemicals is not necessary. The electrolytic treatment is easy to automate, multipurpose, requires only a small area of treatment plant and can cost little to operate. Besides the advantages to public health of not requiring the addition of potentially toxic chemicals, it is an especially clean process, since the electron is the main reactant. Also, it is an efficient method for the removal of pathogens and can be used for disinfection in food processing $(4,6)$ and medical applications (21). Diao et al. (5) tested Escherichia coli disinfection by various treatments, including electrochemical disinfection, chlorination, ozonation and Fenton reaction. Scanning electron microscopy analysis suggested that the electrochemical treatment had a greater effect than the other disinfection processes examined.

This paper is based on the design and testing of a thin layer electrochemical cell for the treatment of artificially contaminated water with Staphylococcus aureus. Although the bactericidal effect by adding chlorine is well known, the goal in this paper was to study the electrochemical effects, such as the bacterial inactivation in the absence of chlorine compounds.

\section{METHODS}

The Gram-positive bacteria $S$. aureus (ATCC6538) were used as a model for disinfection studies. S. aureus is a wellknown infectious agent. Bacteria cells were cultured aerobically in brain-heart infusion (BHI) at $35^{\circ} \mathrm{C}$ for $24 \mathrm{~h}$ and after that kept in refrigerator until 7 days. Before tests, a 1.00 $\mathrm{mL}$ aliquot of cultured cells in BHI was transferred to 100 $\mathrm{mL}$ of nutrient broth (beef extract $3.00 \mathrm{~g}$; peptone $10.00 \mathrm{~g}$, sodium chloride $1.50 \mathrm{~g}$ diluted in $1000 \mathrm{~mL}$ of deionized water). Thus, the culture was shaken in a BOD incubator at $28^{\circ} \mathrm{C}$ for $24 \mathrm{~h}$. Aliquots of $15.0 \mathrm{~mL}$ of this culture were centrifuged at 1.66 " $\mathrm{g}$ " for $10 \mathrm{~min}$, washed in deionized water containing $0.08 \mathrm{M} \mathrm{Na}_{2} \mathrm{SO}_{4}$ and resuspended in $15.0 \mathrm{~mL}$ of $\mathrm{Na}_{2} \mathrm{SO}_{4}$ solution, to give the inoculum's suspension, consisted of young cells free of chloride, for disinfection tests.

The concentration of $S$. aureus suspension was 
determined by colony forming units (c.f.u.) by $\mathrm{mL}$ using the inoculum's suspension diluted in $3.0 \mathrm{~L}$ of $0.08 \mathrm{M} \mathrm{Na}_{2} \mathrm{SO}_{4}$ that results c.f.u. close to $10^{6}$ cells $\mathrm{mL}^{-1}$ that was used at the reservoir during the electrochemical treatment. The samples from the reservoir at the electrochemical system (Figure 1) at different times during the electrochemical treatment operated by batch recirculation mode were diluted and spread uniformly on a nutrient agar plate. After $72 \mathrm{~h}$ incubation at $37^{\circ} \mathrm{C}$, the colony forming units (c.f.u.) were counted and the number of bacteria was calculated for the suspension before and after treatment. In all counts at least three replicate plates were used.
A schematic diagram of the treatment system is shown in Figure 1. It consists of a thin layer electrochemical cell, a hydraulic pump to circulate the solution, a flow meter, a 5.0 $\mathrm{L}$ reservoir, pipes and valves. The components of the thin layer electrochemical cell are housed in a metal structure of dimensions $0.70 \mathrm{~m} \times 0.40 \mathrm{~m} \times 1.00 \mathrm{~m}(1 \times \mathrm{w} \times \mathrm{h})$. The apparatus setup was operated in batch recirculation mode and all experimental runs were carried out with $3 \mathrm{~L}$ of bacteria suspension, i.e., S. aureus.
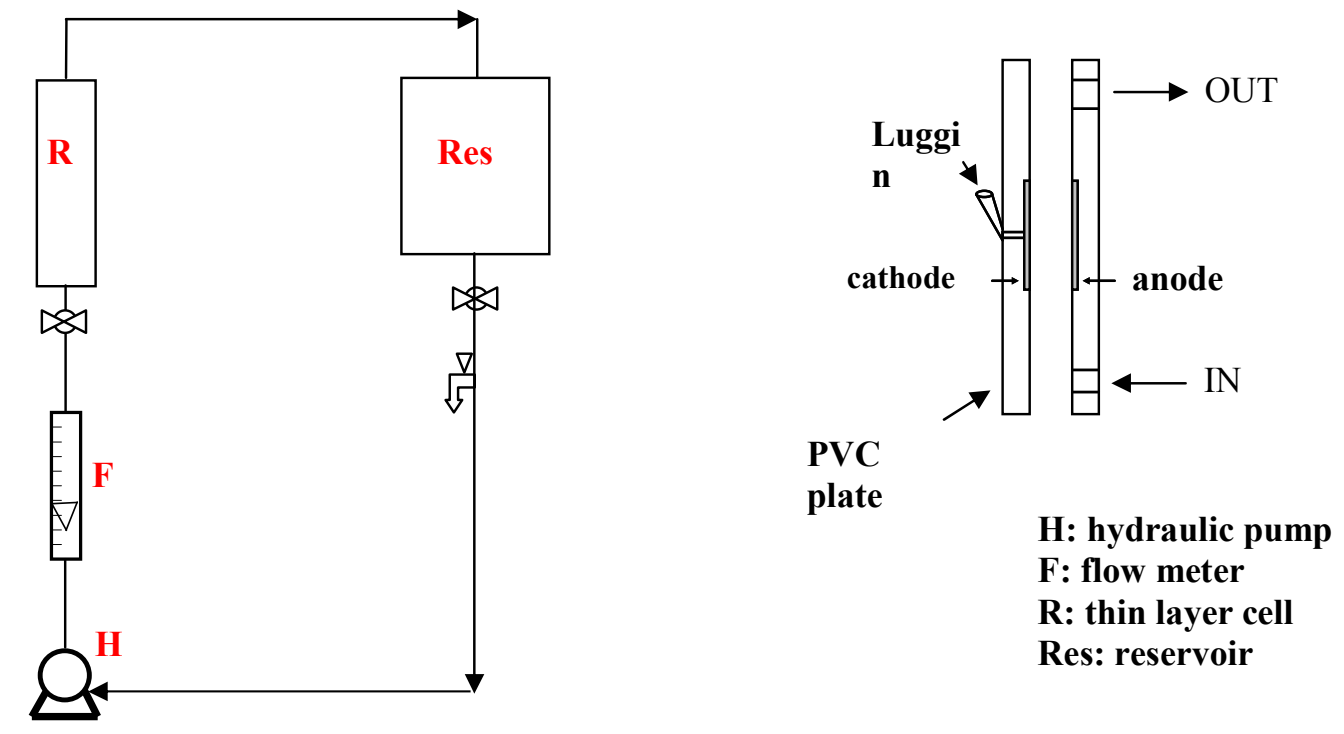

Figure 1: Schematic diagram of the electrochemical system and illustrative view of the thin layer electrochemical cell (right side).

Electrolysis was performed with a low-voltage DC power source (Dawer FCC - 3005D) applying $25 \mathrm{~mA} \mathrm{~cm}^{-2}(1 \mathrm{~A})$ or $75 \mathrm{~mA} \mathrm{~cm} \mathrm{~cm}^{-2}(3 \mathrm{~A})$ at $5.6 \mathrm{~V}$. As anode was used a DSA rectangular electrode of titanium (reaction area $40 \mathrm{~cm}^{2}$ ), coated with an oxide layer of $70 \% \mathrm{TiO}_{2}$ and $30 \% \mathrm{RuO}_{2}(\mathrm{w} / \mathrm{w})$ and a stainless-steel 304 cathode ( $3 \mathrm{~mm}$ from anode) installed inside the single-compartment of thin layer cell made of PVC plates. The DSA is designed for high mechanical strength, high physical and chemical stability over a wide $\mathrm{pH}$-range and insolubility in aqueous media, so that it has a long 
operational life and is not toxic; it also exhibits a high overpotential for oxygen evolution $(8,14)$.

Electrolysis experiments were carried out in suspension with chloride-free $0.08 \mathrm{M}$ sodium sulphate, to determine the bacterial inactivation efficacy of the thin layer cell without the generation of chlorine or adding chemical oxidants. The flow rates were varied $\left(200\right.$ or $\left.500 \mathrm{~L} \mathrm{~h}^{-1}\right)$. All reagents were P.A. grade and also a Digimed DMPH-2 pHmeter and a Tecnopom CA150 conductivimeter were used for physicalchemical analysis.

\section{RESULTS AND DISCUSSION}

The effects of electrolysis on the survival rate of $S$. aureus (at a flow rate of 200 and $500 \mathrm{~L} \mathrm{~h}^{-1}$ ) are shown in Figure 2. As expected, electrolysis plays an important role in the final viability of the cells. S. aureus inactivation increased significantly through electrolysis time, current density and lower flow rate. Thus, $100 \%$ inactivation for $S$. aureus was observed after $30 \mathrm{~min}$ at a potential of $5.6 \mathrm{~V}$, current density of $75 \mathrm{~mA} \mathrm{~cm}^{-2}$ and $200 \mathrm{~L} \mathrm{~h}^{-1}$. However, the Figure 2 shows an intermediary condition with $500 \mathrm{~L} \mathrm{~h}^{-1}$ and $75 \mathrm{~mA} \mathrm{~cm}^{-2}$. In this case, the $S$. aureus inactivation decrease was lower than three logs after $60 \mathrm{~min}$, demonstrating that significant disinfection levels can only be achieved at $200 \mathrm{~L} \mathrm{~h}^{-1}$ and 75 $\mathrm{mA} \mathrm{cm}{ }^{-2}$.

Furthermore, the low power consumption needed to achieve these levels (zero c.f.u. at $200 \mathrm{~L} \mathrm{~h}^{-1}$ and $75 \mathrm{~mA} \mathrm{~cm}^{-2}$ ) is $8.4 \mathrm{kWh} \mathrm{m}^{-3}$, which is a notable feature of this electrolytic treatment. Moreover, the inactivation of $S$. aureus was not caused by chlorine, since the electrolytic medium was absent of chloride ions, which generates chlorine by electrolysis. Consequently, the bactericidal agent under these conditions is believed to be the physiosorbed hydroxyl radicals between electrode and microorganisms. The hydroxyl radicals are formed, as proposed by Comninellis and Platner (3), during the electrolysis of water by anodic catalysis (equation 1):

$$
\mathrm{H}_{2} \mathrm{O}+\mathrm{MO}_{\mathrm{x}} \rightarrow \mathrm{MO}_{\mathrm{x}}\left(\mathrm{OH}^{\bullet}\right)+\mathrm{H}^{+}+\mathrm{e}^{-}
$$

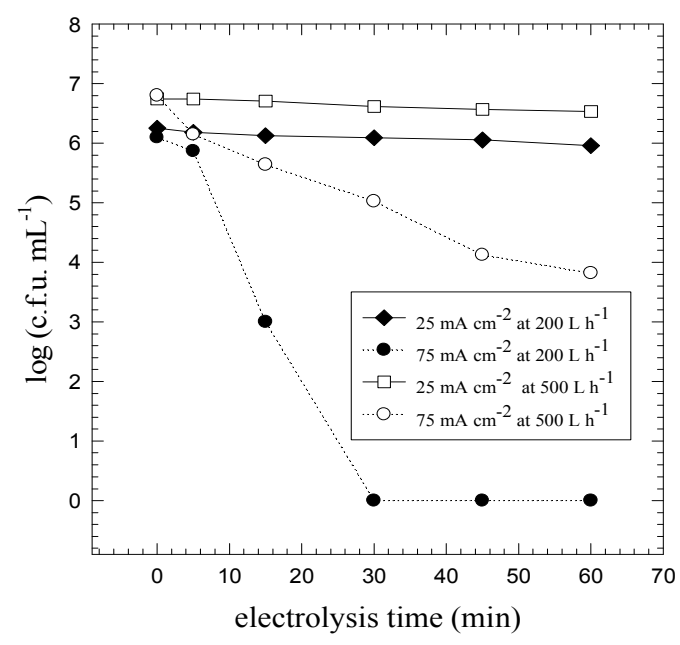

Figure 2: Logarithm of colony forming units (c.f.u.) in function of electrolysis time for different electrical currents and flow-rates.

Thus, increasing the current density increases the rate of $\mathrm{OH}^{\bullet}$ generation that is extremely reactive and, also increases the $\mathrm{H}^{+}$in the vicinity of the anode leading a greater disinfection (Figure 2). The proposal mechanism is that the microorganisms come into contact with the anode surface, get adsorbed onto it, and be oxidized by $\mathrm{OH}^{\bullet}$. This can be interpreted as an electrooxidation, such as electrochemical oxidation of coenzyme A (15) or destabilization of the cell by the transfer of charge from $\mathrm{OH}^{\bullet}(7)$. However, cellular lyses due to the electroporation in the cell membrane due to high electric fields at electrode surface cause damage to the cells (20). In addition to this, low $\mathrm{pH}$ values nearby the electrode 
surface due to the formation of $\mathrm{H}^{+}$on anode during the anodic discharge of water turns unviable the cell machinery.

In the course of these experiments, there was no significant heating due to electrolysis. The temperature increased $5^{\circ} \mathrm{C}$ at most; also, the $\mathrm{pH}$ value observed at suspension was around 7.0 and the conductivity was practically unaltered. Since the solutions did not exhibit any significant rise in temperature or $\mathrm{pH}$ change at bacteria suspension during the electrolysis, $\mathrm{pH}$ of suspension, temperature and conductivity were not responsible for the bacterial inactivation. The data for $75 \mathrm{~mA} \mathrm{~cm}^{-2}$ at $200 \mathrm{~L} \mathrm{~h}^{-1}$ (Figure 2) leads to a first order kinetic as described by equation 2 :

$$
\log \left(\mathrm{N}_{\mathrm{o}} / \mathrm{N}\right)=\mathrm{k} \cdot \mathrm{t}
$$

where No is the initial bacteria cell population that is $1.25 \mathrm{x}$ $10^{6}, \mathrm{~N}$ is $10^{-6}$ cell to be considered a sterile assurance level (SAL) according to Allison (1), $\mathrm{k}$ is the velocity constant and is equal to $0.21 \mathrm{~min}^{-1}$ thus $\mathrm{t}$ is $58 \mathrm{~min}$ to reach a total sterile suspension.

\section{CONCLUSION}

The present study shows that it is possible to obtain a bactericidal effect without generation of chlorine or oxidant compounds. The results infer that is possible to extend the concept for larger-scale disinfection by a thin layer electrochemical cell by simply increasing the number of electrode cassettes and maintaining the power consumption rate. Considering the number of bacteria cells inactivated by the electrolytic process, it becomes efficient for reducing the numbers of potentially pathogenic bacteria and ensuring the safety of the treated water. However the proposed system could not be applied as unique treatment due to legal regulations, as it would be better a combination with other methods, such as UV disinfection for tertiary treatment of potable water. Treated water without chlorine or oxidants compounds can improve human health due to the deleterious effects caused by chemical oxidants in the water.

\section{ACKNOWLEDGEMENTS}

The authors thank FAPESP, CNPq and FUNDUNESP for the financial support.

\section{RESUMO}

\section{Uma Célula Eletroquímica de Camada Delgada para Desinfecção de Água Contaminada com Staphylococcus aureus}

Uma célula eletroquímica de camada delgada foi utilizada e desenvolvida para a desinfecção de água contaminada artificialmente com Staphylococcus aureus. A eletrólise foi executada com uma fonte de corrente direta utilizando $75 \mathrm{~mA} \mathrm{~cm}^{-2}$ (3 A) ou $25 \mathrm{~mA} \mathrm{~cm}^{-2}$ (1 A). Um anodo dimensionalmente estável (DSA) de titânio revestido com uma camada do óxido de $70 \% \mathrm{TiO}_{2}$ e $30 \% \mathrm{RuO}_{2}(\mathrm{w} / \mathrm{w})$ e distanciado por 3 milímetros de um catodo de aço inoxidável 304 foi utilizado para gerar uma camada delgada de suspensão bacteriana passando pela célula de camada delgada. As suspensões utilizadas eram feitas apenas com $\mathrm{Na}_{2} \mathrm{SO}_{4}$ 0,08 $\mathrm{M}$ e livre de íons cloretos de forma a inativar as células bacterianas no tratamento eletroquímico sem a geração de cloro, este pode promover a formação dos trialometanos (THM). As taxas de fluxo em recirculação foram 200 ou $500 \mathrm{~L} \mathrm{~h}^{-1}$. A inativação do $S$. aureus aumentou com o tempo de eletrólise e a uma taxa de fluxo menor. Assim, a inativação de $100 \%$ para o $S$. aureus foi observada após $30 \mathrm{~min}$ a $5,6 \mathrm{~V}$ e $75 \mathrm{~mA} \mathrm{~cm}{ }^{-2}$. Em $500 \mathrm{~L} \mathrm{~h}^{-1}$ e $75 \mathrm{~mA}$ $\mathrm{cm}^{-2}$ a inativação decresceu em três logs de unidades 
formadoras de colônias por $\mathrm{mL}$ após $60 \mathrm{~min}$. O tratamento eletroquímico utilizando uma camada delgada promove a desinfecção completa de $S$. aureus sem a necessidade de adicionar substâncias oxidantes ou a geração de cloro.

Palavras-chave: S. aureus, desinfecção, tratamento de águas, célula de camada delgada

\section{REFERENCES}

1. Allison, G.D. (1999). A review: taking the sterile out of sterility. J. Appl. Microbiol., 87: 789-793.

2. Bergmann, M.E.H.; Koparal, A.S. (2005). Studies on electrochemical disinfection production using anodes containing $\mathrm{RuO}_{2}$. J. Appl. Electrochem., 35: 1321-1329.

3. Comninellis, C.; Platner, E. (1986). Indirect electrolytic oxidation of aromatic compounds. Chimia, 40: 413-416.

4. Deza, M.A.; Araújo M.; Garrido, M.J. (2005). Inactivation of Escherichai coli, Listeria Monocytogenes, Pseudomonas aeruginosa e Staphylococcus aureus on stainless steel and glass surfaces by neutral electrolyzed water. Lett. Appl. Microbiol., 40: 341-346.

5. Diao, H.F.; Li, X.Y.; Gu, J.D.; Shi, H.C.; Xie, Z.M. (2004). Electron microscopic investigation of the bactericidal action of electrochemical disinfection in comparison with chlorination, ozonation and Fenton reaction. Process Biochem., 39: 1421-1426.

6. Feng, C.; Suzuki, K.; Zhao, S.; Sugiura, N.; Shimada, S.; Maekawa, T. (2004). Water disinfection by electrochemical treatment. Bioresour. Technol., 94: 21-25.

7. Fóti, G.; Gandini, D.; Comninellis, C. (1997). Anodic oxidation of organics on thermally prepared oxide electrodes. Curr. Top. Electrochem., 5: 71-78.

8. Inazaki, T.H.; Moraes, P.B.; Pião, A.C.S.; Bidoia, E.D. (2008) Electrolytic treatment of wastewater containing n-phenyl-n'-1,3dimethylbutyl-p-phenylenediamine. Environ. Technol., 29: 553-558.

9. Khaydarov, R.R.; Olsen, R.L.; Rogers, S.E. (2004). Water disinfection using electrolytically generated silver, copper and gold ions. J. Water
Supply Res. \& Technol.-Aqua, 53: 567-572.

10. Kerwick, M.I.; Reedy, S.M; Chamberlain, A.H.L.; Holt, D.M. (2005). Electrochemical disinfection, an environmentally acceptable method of drinking water disinfection? Electrochim. Acta, 50: 5270-5277.

11. Kimbrough, D.E.; Suffet, I.H. (2002). Electrochemical removal of bromide and reduction of THM formation potential in drinking water. Water Res., 36: 4902-4906.

12. Matsunaga, T.; Nakasono, S.; Kitajima, Y.; Horiguchi, K. (1994). Electrochemical disinfection of bacteria in drinking-water using activated carbon-fibers. Biotechnol. Bioeng., 43: 429-433.

13. Matsunaga, T.; Okochi, M.; Takahashi, M.; Nakayama, T.; Wake, H.; Nakamura N. (2000). Tin electrode reactor for disinfection of drinking water. Water Res., 34: 3117-3122.

14. Moraes, P.B.; Bertazzoli, R. (2005). Electro-degradation of landfill leachate in a flow electrochemical reactor. Chemosphere, 58: 41-46.

15. Okochi, M.; Nakamura, N.; Matsunaga, T. (1999). Electrochemical killing of microorganisms using the oxidized form of ferrocenemonocarboxylic acid. Electrochim. acta, 44: 3795-3799.

16. Otenio, M.H.; Panchoni, L.C.; Cruz, G.C.A.; Ravanhani, C.; Bidoia, E.D. (2008) Avaliação em escala laboratorial da utilização do processo eletrolítico no tratamento de águas. Quim. Nova, 31: 508-513.

17. Panizza, M.; Cerisola, G. (2005). Application of diamond electrodes to electrochemical processes. Electrochim. Acta, 51: 191-199.

18. Park, J.C.; Lee, M.S.; Lee, D.H.; Park, B. J.; Han, D.; Uzawa, M.; Takahatori, K. (2003). Inactivation of bacteria in seawater by lowamperage electric current. Appl. Environ. Microbiol., 69: 2405-2408.

19. Sadamura, H.; Kobayashi, S.; Honda, S.; Suzuki, N.; Kogure, M.; Hamashima, H.; Kanzaki, Y. (2000). Electrochemical disinfection of microorganisms using palladium coated carbon cloth electrodes. Electrochemistry, 68: 321-327.

20. Tolentino, R.B.; Bidoia, E.D. (2003). Effects of the electrolytic treatment on Bacillus subtilis. Braz. J. Microbiol, 34: 48-50.

21. Tsuji, S.; Kawano, S.; Oshita, M.; Ohmae, A.; Shinomura, Y.; Miyazaki, Y.; Hiraoka, S.; Matsuzawa, Y.; Kamada, T.; Hori, M.; Maeda, T. (2000). Endoscope disinfection using acidic electrolytic water. Endoscopy, 31: 528-535.

22. Zinkevich, V.; Beech, I.B.; Tapper, R.; Bogdarina, I. (2000). The effect of super-oxidized water on Escherichia coli. J. Hosp. Infect., 46: 153156. 